\author{
Ignacio Martin-Loeches \\ Jordi Valles
}

\section{Overtreating or underdiagnosing invasive pulmonary aspergillosis (IPA) in critically ill H1N1 patients: who is right?}

Received: 19 July 2012

Accepted: 23 July 2012

Published online: 16 August 2012

(C) Copyright jointly held by Springer and ESICM 2012

This editorial refers to the article available at: doi: 10.1007/s00134-012-2673-2.

I. Martin-Loeches $(\bullet) \cdot$ J. Valles

CIBER Enfermedades Respiratorias, Critical Care Centre, Corporación Sanitaria Universitaria Parc Tauli, Parc Taulí

Hospital-Sabadell, Sabadell University Hospital, Universidad Autónoma de Barcelona, Parc Tauli s/n, 08208 Sabadell, Spain e-mail: drmartinloeches@gmail.com

Bacterial co-infection has been found in $\approx 25 \%$ of all influenza-related deaths [1, 2]. However, information regarding the impact of bacterial co-infection in critically ill $\mathrm{H} 1 \mathrm{~N} 1$ patients shows conflicting results. Based on previous reports $[3,4]$, the presence of bacterial co-infection was not associated with increased mortality rates, but was an independent risk factor for severe presentation [5] and showed higher morbidity defined by longer ICU stay. In the pre-antibiotic era, during the 1918-1919 pandemic, the bacteria most often recovered from the sputum, lungs, and blood of pneumonia patients, alive or dead, were common colonizers of the upper respiratory tracts of healthy persons, i.e., H. influenzae, S. pneumoniae, S. pyogenes, and $S$. aureus [6], In this issue of Intensive Care Medicine, Wauters and colleagues [7] present a retrospective analysis of a cohort of 40 adult patients with confirmed H1N1 infection admitted to the ICUs of two tertiary care hospitals. The major finding was that almost $25 \%$ of the patients developed invasive pulmonary aspergillosis (IPA); all of them received corticosteroids (CS) either before or during ICU admission.
Invasive pulmonary aspergillosis represents a dreaded complication in critically ill patients with high mortality rates. Whereas IPA is typically manifested in the immunocompromised host, the epidemiology of IPA in the ICU may be shifting away from those classically considered at risk. The diagnosis of definitive IPA requires histopathologic confirmation; the European Organization for Research and Treatment of Cancer/Invasive Fungal Infections Cooperative Group (EORTC) and the National Institute of Allergy and Infectious Diseases Mycoses Study Group (MSG) published standard definitions for invasive fungal infections for clinical and epidemiological research [8]. Nevertheless, the EORTC/MSG criteria represent a challenge as the clinical manifestations are not specific, and a histological diagnosis is often unfeasible. Some points should be taken into account. Diagnostic criteria such as a "probable IPA" diagnosis based on bronchoalveolar lavage with Aspergillus-positive cultures or galactomannan antigen criteria may not be appropriate in immunocompetent patients because of low sensitivity and may contribute to some patients perhaps being overtreated. Interestingly, in the Wauters study [7], where the IPA diagnosis was based on the EORTC/MSG criteria, all the patients (probable or proven) received CS, and half of them (probable) had traditional risk factors for IPA, but the ICU mortality for IPA versus non-IPA patients was similar (33 vs. $29 \%, p$ 0.8). Based on the previous controversial points, Blot and colleagues developed an alternative clinical algorithm for the EORTC/MSG criteria [9] that attempted to discriminate Aspergillus colonization from IPA in critically ill patients. From a multicenter cohort of 524 patients with Aspergillus-positive endotracheal aspirate cultures, the authors studied $22 \%$ of the patients with histopathologic data. The proposed algorithm had a fairly good sensitivity and negative predictive value that may better identify IPA. Based on the this algorithm, some patients with Aspergillus-positive respiratory findings from the study published by Wauters and 
colleagues might represent colonization, and preemptive or prophylactic therapy would not be appropriate. Whereas the cited algorithm seems to be feasible, it needs to be prospectively evaluated in immunocompetent and/or H1N1 critically ill patients.

Risk factors for IPA include prolonged and severe neutropenia, hematopoietic stem cell and solid organ transplantation, human immunodeficiency virus (HIV), and chronic granulomatous disease, among others [10]. Natural immunity plays a major role in the defense against IPA by recognition and clearance of the organism in immunocompetent hosts. In addition, studies of cellmediated $\mathrm{T}$ cell immunity in humans are lacking, and only conducted in HIV-infected patients in whom dysfunctional CD4 T-cell lymphocytes are well known [11]. The immune response associated with severe viral infections is still unclear. Critically ill H1N1 patients may have an impaired immune response, characterized by a slower control of viral load and the presence of immunodysregulation in those with severe presentation, leading to an unremitting cycle of viral replication and innate cytokine-chemokine release [12]. With the additive effect of a potent anti-inflammatory drug such as CS to critically ill H1N1 patients, several groups have reported the presence of IPA in low rates $(<2 \%)[3,13]$.

In summary, the use of $\mathrm{CS}$ in $\mathrm{H} 1 \mathrm{~N} 1$ critically ill patients may increase the risk of super infections, such as IPA. The high mortality/morbidity of IPA, combined with suboptimal diagnostic tools, has driven the overuse of antifungal drugs. It is imperative to define effective antifungal stewardship tactics based on validated diagnostic and clinical treatment algorithms. Therefore, the true burden of IPA in critically ill H1N1 patients is still unknown. Overtreating or underdiagnosing: who is right?

\section{References}

1. Simonsen L (1999) The global impact of influenza on morbidity and mortality. Vaccine 17(Suppl 1):S3-S10

2. Bhat N, Wright JG, Broder KR, Murray EL, Greenberg ME, Glover MJ, Likos AM, Posey DL, Klimov A, Lindstrom SE, Balish A, Medina MJ, Wallis TR, Guarner J, Paddock CD, Shieh WJ, Zaki SR, Sejvar JJ, Shay DK, Harper SA, Cox NJ, Fukuda K, Uyeki TM, Influenza Special Investigations Team (2005) Influenza-associated deaths among children in the United States, 2003-2004. N Engl J Med 353:2559-2567

3. Martín-Loeches I, Sanchez-Corral A, Diaz E, Granada RM, Zaragoza R, Villavicencio C, Albaya A, Cerdá E, Catalán RM, Luque P, Paredes A, Navarrete I, Rello J, Rodríguez A, H1N1 SEMICYUC Working Group (2011) Community-acquired respiratory coinfection in critically ill patients with pandemic 2009 influenza A (H1N1) virus. Chest 139:555-562

4. Rice TW, Rubinson L, Uyeki TM, Vaughn FL, John BB, Miller RR 3rd, Higgs E, Randolph AG, Smoot BE, Thompson BT, NHLBIARDS Network (2012) Critical illness from 2009 pandemic influenza $\mathrm{A}$ virus and bacterial coinfection in the United States. Crit Care Med 40:1487-1498
5. Viasus D, Paño-Pardo JR, Pachón J, Campins A, López-Medrano F, Villoslada A, Fariñas MC, Moreno A, Rodríguez-Baño J, Oteo JA, MartínezMontauti J, Torre-Cisneros J, Segura F, Gudiol F, Carratalà J, Novel Influenza A (H1N1) Study Group of the Spanish Network for Research in Infectious Diseases (REIPI) (2011) Factors associated with severe disease in hospitalized adults with pandemic (H1N1) 2009 in Spain. Clin Microbiol Infect 17:738-746

6. Brundage JF (2006) Interactions between influenza and bacterial respiratory pathogens: implications for pandemic preparedness. Lancet Infect Dis 6:303-312

7. Wauters J, Baar I, Meersseman P, Meersseman W, Dams K, De Paep R, Lagrou K, Wilmer A, Jorens P, Hermans G (2012) Invasive pulmonary aspergillosis is a frequent complicationof critically ill H1N1patients: a retrospective study. Intensive Care Med. doi: 10.1007/s00134-012-2673-2
8. De Pauw B, Walsh TJ, Donnelly JP, Stevens DA, Edwards JE, Calandra T, Pappas PG, Maertens J, Lortholary O, Kauffman CA, Denning DW, Patterson TF, Maschmeyer G, Bille J, Dismukes WE, Herbrecht R, Hope WW, Kibbler CC, Kullberg BJ, Marr KA, Muñoz P, Odds FC, Perfect JR, Restrepo A, Ruhnke M, Segal BH, Sobel JD, Sorrell TC, Viscoli C, Wingard JR, Zaoutis T, Bennett JE, European Organization for Research and Treatment of Cancer/ Invasive Fungal Infections Cooperative Group, National Institute of Allergy and Infectious Diseases Mycoses Study Group (EORTC/MSG) Consensus Group (2008) Revised definitions of invasive fungal disease from the European Organization for Research and Treatment of Cancer/Invasive Fungal Infections Cooperative Group and the National Institute of Allergy and Infectious Diseases Mycoses Study Group (EORTC/MSG) Consensus Group. Clin Infect Dis 46:1813-1821

9. Blot SI, Taccone FS, Van den Abeele AM, Bulpa P, Meersseman W, Brusselaers N, Dimopoulos G, Paiva JA, Misset B, Rello J, Vandewoude K, Vogelaers D, The AspICU Study Investigators (2012) A clinical algorithm to diagnose invasive pulmonary aspergillosis in critically ill patients. Am J Respir Crit Care Med 186:56-64 
10. Thompson GR 3rd, Patterson TF (2011) Pulmonary aspergillosis: recent advances. Semin Respir Crit Care Med 32:673-681

11. Alimonti JB, Ball TB, Fowke KR (2003) Mechanisms of CD4 + T lymphocyte cell death in human immunodeficiency virus infection and AIDS. J Gen Virol 84:1649-1661
12. Bermejo-Martin JF, Martin-Loeches I, Rello J, Antón A, Almansa R, Xu L, Lopez-Campos G, Pumarola T, Ran L, Ramirez P, Banner D, Ng DC, Socias L, Loza A, Andaluz D, Maravi E, GómezSánchez MJ, Gordón M, Gallegos MC, Fernandez V, Aldunate S, León C,

Merino P, Blanco J, Martin-Sanchez F, Rico L, Varillas D, Iglesias V, Marcos MÁ, Gandía F, Bobillo F, Nogueira B, Rojo S, Resino S, Castro C, Ortiz de Lejarazu R, Kelvin D (2010) Host adaptive immunity deficiency in severe pandemic influenza. Crit Care 14:R167
13. Kim SH, Hong SB, Yun SC, Choi WI, Ahn JJ, Lee YJ, Lee HB, Lim CM, Koh Y, Korean Society of Critical Care Medicine H1N1 Collaborative (2011) Corticosteroid treatment in critically ill patients with pandemic influenza A/H1N1 2009 infection: analytic strategy using propensity scores. Am J Respir Crit Care Med 183:1207-1214 